\title{
An Econometric Estimation of Tax-discounting in Pakistan
}

\author{
AQDAS ALI KAZMI
}

The debt neutrality hypothesis which has been a source of major controversies in the theory of public finance, and macroeconomics has at the same time generated a vast literature on the implications of budgetary deficits and public debt on various subsectors/variables of the economy, such as inflation, interest rates, current account deficit, etc. Tax discounting has been one of the fields of research associated with debt neutrality. The econometric estimation of some of the standard models of taxdiscounting has shown that consumer response to fiscal policy in Pakistan reflects neither the extreme Barro-like rational anticipation of future tax liabilities nor the Buchanan-type extreme fiscal myopia. It broadly follows a middle path between these extremes.

The controversy relating to debt neutrality is quite old in economic theory. However, due to its serious and far-reaching implications for the formulation of fiscal policy and macroeconomic management, the issues of debt neutrality have assumed a foremost position in economic theoretisation and empirical testing. This controversy is based on two important questions:

(a) Who bears the burden of the debt?

(b) Should debt be used to finance public expenditure?

The first question centres on whether the debt can be shifted forward in time, while the second question explores whether taxation is equivalent to debt in its effects on the national economy.

Since issuance of debt implies that either the debt must be re-paid in the future or the interest on the debt must be paid in perpetuity, the tax-payers have a liability in the form of future tax payment, which has a value just equal to the present value of the

Aqdas Ali Kazmi is Economic Consultant, Ministry of Commerce, Islamabad.

Author's Note: This paper is based on a sub-section of Chapter VI of my Ph.D. dissertation entitled "Savings, Consumption, and Ricardian Equivalence: A Macroeconometric Analysis of Pakistan: 1960-80" submitted (1991) to Boston University, USA. I am grateful to my Dissertation Committee, comprising Prof. John Harris, Prof. Gustav F. Papanek, Prof. Fabio Schiantarelli, Prof. Kenneth Chomitz, and Prof. Gary Koop, for their continuous help and guidance. I am grateful to Professor Robert Barro (Harvard University) for his guidance at the initial stages of writing the dissertation. Thanks are also due to my fellow Ph.D. student Mr Oscar Malhado from El Salvador for his computational assistance. However, none of the above is responsible for the shortcomings/omissions of this paper. 
government bond sold in the market. The creation of the asset of bonds is just offset by the creation of the liability of future taxes.

The issue of debt neutrality has been brought into the limelight with the publication of Barro's (1974) seminal article in which he advanced the hypothesis that taxation and debt are equivalent, and this equivalence was established by developing a model of intergenerational transfers. In his numerous papers and writings, which have been published continuously since 1974, Barro (1976, 1978, 1979, 1981, 1987, 1989) has focused on establishing the viability and rationality of debt neutrality, using both theoretical framework and empirical estimates.

The major opposition to Barro's hypothesis has come from Buchanan, who has postulated that fiscal illusion creates a wedge in the equivalence of taxation and debt. He has asserted that while bond assets are fully capitalised by the buyers, tax-payers invariably fail to take full account of the future tax liability at the time of debt issue. Consequently, the bonds are perceived by the bond-holders as net addition to wealth which raises the level of present consumption. This reduces present investment and thus lowers the stock of capital for the future generations.

The debt neutrality hypothesis has been a catalyst of vast research, both theoretical and empirical, on the relationship between debt accumulation and various sub-sectors/parameters of the economy such as interest rate, inflation rate, budget deficit, and current account deficit, etc. The precise determination of tax discounting is an important development in the field of economic research relating to the debt neutrality controversies.

A synthesis of the literature on conflicting hypothesis and divergent empirical tests related to debt neutrality, or Ricardian Equivalence Hypethesis, is given in Buiter and Tobin (1979), Tobin (1980), Bernheim (1987), Kazmi (1991, 1992, 1994), and Seater (1993).

The basic argument advanced by the exponents of debt neutrality hypothesis, i.e., taxation and debt are equivalent, is based upon a model of intergenerational linkages suggesting that substituting one dollar of debt for one dollar of taxation will increase saving by one dollar in order to offset the future tax liabilities. On the other hand, the opponents of the neutrality hypothesis base their case on the argument that bond-holders suffer from "myopia", and as such future tax liability will not be capitalised and the substitution of one dollar of debt for one dollar of taxation will not cause saving to increase by the amount of the newly issued debt.

\section{THE HOLCOMBE, JACKSON AND ZARDKOOHI MODEL}

Even though a comprehensive review of the literature is not possible, among the important studies on debt neutrality which have primarily focused on tax-discounting in developed countries are Kochin (1974), Koskela and Viren (1983), Seater (1982, 1985), Tanner (1979), Yawitz and Meyer (1976), Feldstein (1982), etc. Studies on estimation of 
tax-discounting for developing countries are rather limited. However, the results of empirical tests conducted for a developing economy like Pakistan are presented in Kazmi (1991). These results generally fail to find support for the Barro's ultra-rationality embodied in the Ricardian Equivalence Hypothesis.

The empirical work on estimating tax-discounting for the US was initiated by Holcombe, Jackson, and Zardkoohi (1981) in their model of personal saving function which has the following specification:

$$
\begin{aligned}
& S=a 0+a \mathrm{l} Y p+a 2 Y t+a 3 L a+a 4 R+a 5 P \\
& +a 6 P c+a 7 U+a 8 d U \quad \ldots \quad \ldots \quad \ldots
\end{aligned}
$$

When $\quad S=$ real per capita personal savings.

$Y p=$ real per capita temporary income.

$Y t=$ real per capita temporary income, i.e., actual $Y$ (income) minus $Y p$.

$R=$ nominal interest rate (Aas Moody's yield).

$P=$ actual inflation rate.

$P e=$ expected inflation rate $=P-P E$.

$L a=$ real per capita liquid assets.

$U=$ unemployment rate.

$d u=$ change in unemployment rate.

The regression model of Holcombe et al. (1981) is based on the revised version of the Howard model which assumes the form:

$$
\begin{aligned}
& S=b 0+b 1 Y p+b 2 Y t+b 3 G+b 4 D+5 L a+b 6 R+b 7 P+ \\
& 8 P e+b 9 U+b 10 d U \quad \ldots \quad \ldots \quad \ldots \quad \ldots \quad \ldots
\end{aligned}
$$

The additional terms employed in the model are:

$G=$ real per capita government spending.

$D=$ real per capita domestic debt.

$W=$ dummy variable for the World War II.

In this model, the measure of transitory income, $Y t$, is obtained by subtracting permanent income from the actual. The coefficient $b 2$ in Equation (1) is expected to have a positive sign on the premise that an increase in transitory income leads to an increase in savings. The measure of liquid assets, $L a$, is defined by the authors as real per capita value of personal sector's holding at the beginning of the period, net liquid assets, which consist of holding of cash, demand deposits, time deposits, saving and association loan shares, and saving bonds. The variable, $L a$ is included in the model on the assumption that the household's stock of net liquid assets may influence its short-run saving behaviour separately from its role as a component of household wealth. Holcombe et al. have supported the Howard premise that 'a certain amount of liquid assets is needed to conduct transactions; thus if the real value of liquid assets diverges 
sufficiently from the desired amount, saving will be adjusted in order to restore holdings to the desired level'. Interest rate, $R$, is included in saving functions to measure the interest elasticity of personal savings, while $P$ and $P e$ capture the effects of actual and expected inflation, respectively. The variables $U$ and $d U$ capture the effects of the unemployment rate and its yearly change. The variable, $d U$, is included as a proxy for expectations concerning the future unemployment rate.

Holcombe et al. hypothesise the following signs for the variables:

$$
\begin{aligned}
d S / d L a<0 ; d S / d r & \leq 0 ; \\
& \geq 0 ; d S / d u \leq 0 \\
d s / S p<0 ; d S / d P e & \leq 0 ; d S / d u>0 .
\end{aligned}
$$

\section{Estimation of Tax Discounting for the US}

This model was estimated by OLS for the US using annual data of 48 years for the period 1929-76. The results of this model are given in Table 1, Column 1 . Holcombe et al. (1981) however, realising that because of the relatively large number of insignificant variables and theoretically invalid sign on $Y p$ (which showed the presence of multicollinearity), estimated a revised model in which the variables $R$ (the nominal interest rate) $P e$ (expected inflation rate), and $U$ (unemployment rate) were dropped due to their statistical insignificance. The modified model, which was used to estimate the impact of public debt on private saving, led to a new version of the tax-discounting model, the results of which are given in Equation (2) of Table 1.

As the results indicate, except for the coefficient sign of the liquid asset, all other signs are in accord with the expectations. According to Holcombe et al., "one conceivable explanation for the positive sign on the liquid asset could be the fact that the data is yearly. (Howard used quarterly data and obtained a negative sign.) In the aggregate for the year, the impact of an adjustment process between variations in liquid assets and savings could have been obscured. In other words, the choice of yearly data for investigating the impact of the liquid asset variable on the saving variable could be inappropriate, resulting in a positive sign".

In the model, the critical variable, however, is $D$, the real per capita debt. In Equation (2) the coefficient on public debt equals 0.2 , which is statistically greater than zero and statistically less than one at the 0.0001 level of significance. This implies that for a one dollar increase in the public debt, savings increase by twenty cents. In other words, the results indicate that 20 percent of additional public debt is capitalised in terms of saving and the remaining portion is not capitalised, implying that 80 percent of the burden of the national debt is passed on to the future "generations". Since such an overwhelmingly large percentage of the future tax liability associated with the national debt is not capitalised, the authors conclude that the empirical results suggest "the dominance of the hypothesis that taxation and debt are not equivalent means of public 
Table 1

U.S. Personal Saving Functions Tax-discounting in U.S. 1929-1976 (OLS Estimation)

\begin{tabular}{|c|c|c|c|c|}
\hline & (1) & $(2)$ & (3) & (4) \\
\hline \multirow[t]{2}{*}{ C } & -12.72 & -39.19 & -51.96 & -83.25 \\
\hline & $(-0.16)$ & $(-2.87)$ & $(-0.70)$ & $(-3.35)$ \\
\hline \multirow[t]{2}{*}{ Yp } & -0.10 & - & -0.07 & - \\
\hline & $(-2.16)$ & & $(-1.74)$ & \\
\hline \multirow[t]{2}{*}{ Yt } & 0.76 & 0.42 & 0.97 & 0.46 \\
\hline & (4.33) & (6.15) & (3.65) & (3.24) \\
\hline \multirow[t]{2}{*}{ G } & 0.22 & 0.07 & 0.40 & 0.30 \\
\hline & (3.48) & (2.78) & $(4.80)$ & (3.81) \\
\hline \multirow[t]{2}{*}{ D } & 0.11 & 0.20 & -0.05 & 0.04 \\
\hline & (1.73) & (4.71) & $(-0.72)$ & $(0.60)$ \\
\hline \multirow[t]{2}{*}{$\mathrm{T}$} & - & - & -0.66 & -0.40 \\
\hline & & & $(-3.85)$ & $(-3.05)$ \\
\hline \multirow[t]{2}{*}{$\mathrm{P}$} & 944.15 & 78.68 & 1117.4 & 1008.8 \\
\hline & (3.97) & (2.34) & $(4.91)$ & (5.61) \\
\hline \multirow[t]{2}{*}{$\mathrm{Pe}$} & -82.72 & - & -520.6 & - \\
\hline & $(-0.20)$ & & $(-1.39)$ & \\
\hline \multirow[t]{2}{*}{$\mathrm{La}$} & 0.04 & 0.03 & 0.06 & 0.03 \\
\hline & (3.77) & (4.19) & $(4.71)$ & (4.61) \\
\hline \multirow[t]{2}{*}{$\mathrm{U}$} & - & - & -382.5 & - \\
\hline & & & $(-1.06)$ & \\
\hline \multirow[t]{2}{*}{ dU } & 1066.87 & 806.66 & 1298.8 & 946.61 \\
\hline & (2.32) & (3.55) & (2.43) & (2.26) \\
\hline \multirow[t]{2}{*}{$\mathrm{R}$} & 759.02 & - & 3389.7 & - \\
\hline & $(0.55)$ & & (2.35) & \\
\hline \multirow[t]{2}{*}{ W } & 35.71 & 0.07 & 13.11 & 18.39 \\
\hline & $(0.93)$ & (2.78) & $(0.36)$ & $(0.49)$ \\
\hline R2 & 0.97 & 0.97 & 0.978 & 0.973 \\
\hline W & 2.13 & 2.29 & 1.70 & 1.96 \\
\hline $\mathrm{F}$ & 98.92 & 185.53 & 108.84 & 145.64 \\
\hline
\end{tabular}


finance. Substituting debt for tax finance shifts much of the burden of public expenditures forward in time through lower rates of saving and capital accumulation".

The authors place high confidence in this equation as most of the variables in this equation have expected signs and are significant at the 0.01 level. The coefficient on government expenditures, $G$, is positive, indicating that an increase in $G$ leads to an increase in income, which in turn leads to an increase in savings. The coefficient on the dummy variable, $W$, is positive, implying that during World War II "forced saving" resulted in an overall savings in the United States: \$78 per year per person in 1972 prices. According to the authors, the positive coefficient on $d U$ implies that an increase in expected unemployment rate leads to an increase in savings. In other words, in good times people save for their expected bad times. The coefficient on the transitory income is less than one and is positive, implying that a one dollar increase in the unexpected income increases savings as well as consumption. The empirical results indicate that for each dollar of transitory income, savings increase by about 42 cents, and thus consumption increases by 58 cents.

\section{Carmichael's Critique}

After critically examining the Holcombe, Jackson and Zardkoohi model of debt neutrality, Carmichael (1982) has highlighted a serious shortcoming of the model as a tool of measuring tax-discounting.

He has suggested that to interpret the coefficients in an equation such as (2) above correctly in terms of the hypotheses in question, it is essential to bear in mind exactly what those hypotheses are claiming. Barro's equivalence hypothesis claims that a one dollar swap of debt for taxes, with the level of government spending held constant, will have no real effects on the economy. That is, since the debt raises the stock of new assets by one dollar, the demand for those assets (i.e., savings) must also increase by one dollar in order to leave the demand for capital unchanged. Therefore, the correct comparative static exercise according to Carmichael should be:

$$
\frac{\partial S}{\partial D} \quad\left|\partial G=0 \quad-\frac{\partial S}{\partial T}\right| \partial G=0^{=1}
$$

where $T$ is total taxes. Carmichael has pointed out that it is the second term of the lefthand side of this equation that is ignored by the authors and others who have investigated this issue. "It is insufficient to look at the debt coefficient in isolation, since the hypothesis involves substituting a dollar of debt for a dollar of tax; lower taxes mean higher savings through an increase in disposable income".

Since the tax effect in Equation (2) comes through the transitory income term, a once-for-all swap of debt for tax will lower taxes in the current period only, so that 
transitory disposable income is increased in the current period. From Equation (2) the response $d S / d T=-0.42$ so that $d S / d D-d S / d T=0.62$. Barro's equivalence theory is then tested by comparing this combined coefficient with unity. The $t$ value for this hypothesis is 3.45, which rejects Barro's complete discounting argument, although the degree of discounting is well above the 20 percent figure quoted by Helcombe et al. (1981).

It is further claimed by Carmichael that the estimated degree of discounting, calculated on the above basis, is 87 percent, and in this case the data are unable to reject the hypothesis that $d S / d D-d S / d T=1$, the $t$ value for this hypothesis is 0.565 . "Since the preference for (2) over (1) is in part arbitrary, the results cannot be viewed as strongly supportive of Barro's position, or as rejecting it conclusively. At the same time, however, conclusions based only on considerations of the coefficient on debt seriously under-estimate the degree to which debt is discounted into savings".

\section{The Revised Holcombe, Jackson and \\ Zardkoohi Model}

In the light of Charmichael's criticism, Holcombe et al. (1982) revised their model and developed the underlying logic of tax-discounting through Equations (3) to (6) below:

$$
S=S(D, T, G, Z i), i=4 \ldots . n \quad \ldots \quad \ldots \quad \ldots \quad \ldots
$$

Where $D$ is public debt, $T$ is taxes, $G$ is government spending, and $Z i$ is a vector of monetary, demographic, and other variables.

$$
\begin{aligned}
& d S=\partial S / \partial D . d S+\partial S / \partial T \cdot d T+\partial S / \partial G . \\
& \begin{array}{llllll}
d G+ & \partial S / \partial Z \cdot d Z & \ldots & \ldots & \ldots & \ldots
\end{array}
\end{aligned}
$$

Holding Zi constant,

$$
d S=\quad \partial S / \partial D \cdot d S+\partial S / \partial T \cdot d T+\partial S / \partial G \cdot d G \ldots \quad \ldots
$$

Equation (5) can be manipulated to measure the extent to which debt increases are capitalised into savings. Holding government spending constant $(d G=0)$ and replacing a given amount of taxes with an equal amount of debt $[d D=-d T]$, what is the effect on private savings (i.e., what is $d S / d D$ )? The relevant substitutions into (5) generate the following tax-discounting measure:

$$
d S / d D=\partial S / \partial D-\partial S / \partial T \quad \ldots \quad \ldots \quad \ldots
$$


From Equation (6) it can be seen that if the coefficient of taxes ( $T$ ) in the saving function is negative and significant, then the sum of tax $(T)$ and debt $(D)$ coefficient would determine the extent of tax-discounting. If $d S / d D=0$, Buchanan's pure fiscal illusion prevails and if $d S / d D=1$, Barro's equivalence hypothesis is verified. The values between zero and one indicate the exact extent of tax-discounting.

The revised equations are estimated by the authors and the results are produced in Table 1 in Equations (3) and (4). The tax-discounting for US now comes to 0.61 and 0.44 , respectively.

\section{Estimation of Tax Discounting for Pakistan}

From the above discussion, it is well-established that the strong version of Barro's equivalence hypothesis claims that future tax liabilities implicit in debt issue are fully discounted, such that a one dollar swap of debt for taxes with the level of government spending held constant has no real effect on the economy. The obvious implication of debt-neutrality is that since the debt raises the stock of new assets by one dollar, the demand for those assets (i.e., savings) must also increase by one dollar in order to leave the demand for capital unchanged. This dollar increase in private savings in response to a dollar increase in public debt represents complete or 100 percent taxdiscounting (or debt-capitalisation) which is assumed in Barro's theoretical model.

The following basic model of private savings was estimated to quantify the extent of tax-discounting for Pakistan:

$$
\begin{aligned}
P s= & b 0+b 1 Y p+b 2 Y t+b 3 G+b 4 T+b 5 D+ \\
& b 6 P+b 7 P c+b 8 L a+b 9 U+v
\end{aligned}
$$

Where $P s=$ Private real savings per capita.

$Y p=$ Permanent income, i.e., the three year average of the current year income and the post two years.

$Y t=$ Temporary income, i.e., actual $Y$ (income) minus $Y p$.

$G=$ Government spending.

$T=$ Taxes.

$D=$ Flow of debt, i.e., the net debt accumulated.

$P e=$ Expected inflation: the three year average of current inflation rate and the past two years' inflation rate.

$P=$ Actual inflation rate.

$L a=$ Liquid assets.

$U=$ Unemployment rate.

$v=$ Error term. 
The estimates of the model are given in Table 2 and the values of tax-discounting co-efficient based on the equation of this table are given in Table 3 below.

Table 2

Pakistan Private Saving Functions: Tax-discounting in Pakistan:

1960-88 (OLS Estimation)

\begin{tabular}{lccccc}
\hline & $(1)$ & $(2)$ & $(3)$ & $(4)$ & $(5)$ \\
\hline $\mathrm{C}$ & -2.052 & -12.73 & -8.941 & 0.816 & 5.705 \\
& $(-0.118)$ & $(-0.913)$ & $(-0.543)$ & $(0.055)$ & $(0.381)$ \\
$\mathrm{Yp}$ & 0.034 & 0.051 & 0.033 & 0.05 & 0.05 \\
& $(0.471)$ & $(0.890)$ & $(0.457)$ & $(0.894)$ & $(0.780)$ \\
$\mathrm{Yt}$ & 0.223 & - & - & 0.219 & 0.415 \\
& $(1.378)$ & - & - & $(1.438)$ & $(1.914)$ \\
$\mathrm{G}$ & 0.087 & 0.073 & 0.118 & 0.117 & 0.048 \\
& $(0.529)$ & $(0.478)$ & $(0.640)$ & $(0.857)$ & $(0.260)$ \\
$\mathrm{D}$ & 0.485 & 0.51 & 0.551 & 0.465 & 0.668 \\
& $(1.721)$ & $(2.295)$ & $(2.263)$ & $(1.780)$ & $(2.990)$ \\
$\mathrm{T}$ & 0.137 & 0.045 & -0.010 & 0.146 & 0.219 \\
& $(0.375)$ & $(0.137)$ & $(0.029)$ & $(0.478)$ & $(0.576)$ \\
$\mathrm{P}$ & -32.123 & - & - & -57.564 & - \\
& $(-0.348)$ & - & - & $(-1.489)$ & - \\
$\mathrm{Pe}$ & -54.245 & - & - & - & - \\
& $(-1.088)$ & - & - & - & - \\
La & 0.063 & 0.111 & 0.106 & - & - \\
& $(0.366)$ & $(1.098)$ & $(1.021)$ & - & - \\
$\mathrm{dU}$ & - & - & -295.165 & - & -481.527 \\
& - & - & $(-.455)$ & - & $(-0.608)$ \\
$\mathrm{R} 2$ & 0.811 & 0.814 & 0.797 & 0.828 & 0.813 \\
$\mathrm{D} . \mathrm{W}$. & 1.808 & 1.942 & 2.027 & 1.826 & 1.991 \\
$\mathrm{~F}$ & 15.515 & 23.221 & 8.689 & 22.677 & 20.591 \\
\hline
\end{tabular}

Table 3

Pakistan: Quantification of Tax-discounting

\begin{tabular}{cc}
\hline Equation & Extent of Tax-discounting \\
\hline II.1 & 0.485 \\
II.2 & 0.510 \\
II.3 & 0.551 \\
II.4 & 0.465 \\
II.5 & 0.668 \\
\hline
\end{tabular}




\section{Limitations and Critique}

The model used in this paper and the results achieved are subject to numerous caveats and thus limit its usefulness in a number of ways.

We have estimated a traditional model of private savings which has been designed to measure the tax-discounting in Pakistan. However, we have not tested the sensivity of this model by using econometric techniques other than OLS estimation.

Considering the multiplicity of variables from the fiscal side such as taxes, government spending, and public debt, the multicollinearity problem is reflected in low $t$-statistics for the variables of tax and government spending. Similarly, the multicollinearity problems is also visible in the variable of permanent income ( $Y p)$ and temporary income $(\mathrm{Yt})$.

Notwithstanding all these limitations, it could be pointed out that in the traditional model the value of tax-discounting is fairly stable in the range of 0.465 to 0.668 , leading to the conclusion that the consumers in a developing country like Pakistan do not suffer from "pure fiscal illusion" but, at the same time, they do not have the ultra-rationality and perfect foresight for full tax-discounting as postulated in Barro’s model.

\section{REFERENCES}

Barro, Robert J. (1974) Are Government Bonds Net Wealth? Journal of Political Economy 82:6 1095-1117.

Barro, Robert J. (1976) Reply to Perceived Wealth in Bonds and Social Security and Barro on the Ricardian Equivalence Theorem. Journal of Political Economy 84:2 343-349.

Barro, Robert J. (1978) The Impact of Social Security on Private Saving. Evidence from the U. S. Time Series. Washington, D. C.: American Enterprise Institute.

Barro, Robert J. (1979) On the Determination of the Public Debt. Journal of Political Economy 87:5 940-971.

Barro, Robert J. (1981) Output Effects of Government Purchases. Journal of Political Economy 89:6 1086-1121.

Barro, Robert J. (1987) Government Spending, Interest Rates, Prices, and Budget Deficits in the United Kingdom, 1701-1918. Journal of Monetary Economy 20:2 221-247.

Barro, Robert J. (1989) The Ricardian Approach to Budget Deficits. Journal of Economic Perspectives 3:2 37-54.

Bernheim, B. Douglas (1987) Ricardian Equivalence: An Evaluation of Theory and Evidence. In Stanley Fishcher (ed) Macroeconomics Annual. Boston, Mass. MA.: National Bureau of Economic Research.

Buiter, W. H., and J. Tobin (1979) Debt Neutrality: A Brief Review of Doctrine and 
Evidence. In G. M. von Furstenberg (ed) Social Security versus Private Saving. Cambridge, MA.: Ballinger Publishing Company. 39-63.

Carmichael, J. (1982) The National Debt Controversy: A Comment. Kyklos 35:4 710712.

Feldstein, M. (1982) Government Deficits and Aggregate Demand. Journal of Monetary Economics 10:1-20.

Holcombe, R. G., J. D. Jackson, and A. Zardkoohi (1981) The National Debt Controversy. Kyklos 34:186-202.

Holcombe, R. G., J. D. Jackson, and A. Zardkoohi (1982) The National Debt Controversy: A Reply. Kyklos 35: 713-718.

Kazmi, Aqdas Ali (1991) Savings, Consumption and Ricardian Equivalence: A Macroeconometric Analysis of Pakistan: 1960-80. Ph.D Dissertation submitted to Boston University, U.S.A.

Kazmi, Aqdas Ali (1992) Ricardian Equivalence: Some Macroeconometric Tests for Pakistan. The Pakistan Development Review 31:4 743-758.

Kazmi, Aqdas Ali (1994) Private Consumption, Government Spending and Debt Neutrality; Resolving: Kormendi-Feldstein-Modigliani Controversy. The Pakistan Development Review 33:4 1055-1071.

Kochin, Levis A. (1974) Are Future Taxes Anticipated by Consumers? Comments. Journal of Money, Credit, and Banking 6:3 385-394.

Koskela, Erkki, and Matti Viren (1983) Social Security and Household Saving in an International Cross Section. American Economic Review 73:1 212-217.

Seater, John J. (1982) Are Future Taxes Discounted? Journal of Money, Credit, and Banking 10:3 376-390.

Seater, John J. (1985) Does Government Debt Matter? A Review. Journal of Monetary Economics 16:1 121-131.

Seater, John J. (1993) Ricardian Equivalence. Journal of Economic Literature 31: March.

Tanner, J. Ernest (1970) Empirical Evidence on the Short-run Real Balance Effect in Canada. Journal of Money, Credit, and Banking 2:4 473-485.

Tanner, J. Ernest (1979) An Empirical Investigation of Tax Discounting. Journal of Money, Credit, and Banking 11:2 214-218.

Tanner, J. E. (1979) An Empirical Investigation of Tax Discounting: A Comment. Journal of Money, Credit, and Banking 11:2 214-218.

Tobin, James (1980) Asset Accumulation and Economic Activity. Chicago, IL: University of Chicago Press.

Yawitz, J. B., and L. H. Meyer (1976) An Empirical Investigation of the Extent of Tax Discounting. Journal of Money, Credit, and Banking 8: 248-254. 